\title{
Telling the story of the Computer Geek: children becoming authors and translators
}

I never imagined that I would actually make a book, and, reading all those English and Albanian books, and now when I think, when I read an English book, I'm always, like, 'I've made a book as well. (Magda, aged 10)

\section{INTRODUCTION}

London is the most multilingual city in the world, with over 230 languages (Eversley et al, 2010) spoken by the children in its schools. Since the 1990s, political unrest in many parts of the world, ecological catastrophes, globalisation and the enlargement of the European Union have increased both the scale and the nature of migration (Vertovec, 2007). While new communities have widely dispersed within the UK, the east of London has maintained its position as the first port of call for many new migrant communities.

As the range of languages spoken by school children has expanded, it is not uncommon for individual primary schools to have 40 different languages spoken, with secondary schools having many more. In spite of the long history of migration, the English education system is profoundly ambivalent about its pupils' bilingualism (Conteh et al, 2007). It is only fairly recently that the language skills of young children of migrant origin have begun to be considered as a resource rather than a problem (Ruíz, 1984; DfES, 2003; 2006) and the benefits of bilingualism recognised (CILT, 2007). The curriculum remains resolutely monolingual and monocultural and while there is some teaching of community languages in both primary (DfES, 2002) and secondary schools, this is very limited and frequently held after hours. Bilingual education is not currently available in mainstream schools. Many children lose active use of the language of their families once they start school, as a result of lack of status and recognition of the language and lack of opportunity for learning it. However, while the official curriculum makes minimal reference to bilingualism, individual teachers and schools have developed their own pedagogies to support and develop the language skills of their multilingual school populations. There are a number of examples of such mainstream schools building links with complementary schools (also known as supplementary or mother-tongue schools) (CILT, 2007) organised by communities themselves, after school and at week-ends, to teach the languages of their country of origin. The girls who feature in this study benefited from such teachers as they developed their biliteracy.

\section{ISSUES IN PEDAGOGY}

The work of Cummins is well known to many teachers who work with bilingual pupils. He has highlighted the importance of the level of development of bilingual children's mother tongue and the impact this has on the learning of a second language (Cummins, 1984). When skills and concepts have been developed in the first language they transfer readily to the second, ensuring a rapid development which is independent of the amount of instruction. This transfer operates particularly successfully in academic and literacy skills. The transfer operates even where languages and scripts differ notably, though the extent and nature of the transfer varies depending on the relationship between the two languages concerned 
(Bialystok, 2001). Of particular relevance to the present study is the fact that the transfer of literacy skills operates both ways, so that children who have become dominant in the language of the school can make use of the reading skills acquired in school to become literate in the language of the home. The present study shows how Magda and Albana made use of the skills acquired in the English classroom and their understanding of how language works, to learn to read and write in the language of the home (Cummins, 2001a).

The Cummins' model of empowerment for minority students offers four key points that would determine success in education: valuing and incorporating the language of the home, working in partnership with parents and communities, an interactive style of teaching and fair assessment (1986; 1996; 2001b). He offers a model of transformative pedagogy

...which promotes identities of competence among students from marginalised community groups, thereby challenging the devaluation of these students' cultures and languages in the wider society (Cummins et al, 2011:31)

The present study shows teachers developing a pedagogy that makes use of bilingual strategies to develop reading skills and language awareness through working simultaneously across two languages. They support the writing of personal narratives in two languages and publish them within the school. Cummins' has described the power of such "identity texts' (Cummins et al, 2006; Cummins, 2011) to support language learning, build confidence and affirm personal identities.

Traditionally bilingual teaching programmes have kept the two languages separate. However a pedagogy of 'flexible bilingualism' (Blackledge \& Creese, 2010) or translanguaging (García, 2009) is developing in sites of multilingual education. Recent ethnographic studies of language pedagogy in complementary schools reveal how languages as diverse as Gujarati, Mandarin, Turkish and Bengali are used together with English to support learning (Martin et al, 2006; Blackledge \& Creese, 2010). Kenner et al (2008a; 2008b), in a study of young Bangladeshi children in east London schools, has explored how mainstream and complementary school teachers working together have developed creative strategies that have helped children to gain a deeper understanding of poetry or mathematics.

For students who are fairly fluent in their heritage language, Cummins specifically recommends the "creation of student-authored dual language books by means of translation from the initial language of writing to L2" (Cummins,1999: 589). Such a strategy offers pupils an opportunity to explore and analyse the similarities and differences between their languages; working with different syntactic structures and the very different range of meanings that equivalent words have in different languages can develop metalinguistic skills and critical literacy. Students involved in such activities have reported the benefit to their English language skills, and this is very much what has been noted regarding the children in the present study as use translation to teach themselves to write in Albanian.

\section{TRANSLATION AS A RESOURCE IN BILINGUAL DEVELOPMENT}

As they moved from reading to writing bilingually, Magda and Albana produced their narrative sequentially in two languages, translating from a stronger language to a weaker one. While the role of children as community interpreters has been well documented in the 
US (Valdés, 2003) and in the UK (Hall, 2004; Hall \& Robinson, 1999), the literature on young bilingual children translating is sparse and little of it is recent (Malakoff and Hakuta, 1991). Harris developed the concept of natural translation which he defined as "the translating done in everyday circumstances by people who have no special training for it" (Harris and Sherwood, 1978:1). He argues that, within the limits of their mastery of two languages, translating is a natural skill for all bilinguals: a third bidirectional cognitive competence to add to their ability in two languages. Harris' data suggest that children, when translating, focus on communicating the message rather than on the production of completely correct sentence structure or syntax in the target language. He notes that, as children who are bilingual are mostly bicultural, their acts of translation generally demonstrate a command of the cultural context in which their languages operate.

In a review of the relationship between bilingualism and untutored translation, Kaya (2007) discusses Catford's theory that translation "implies the substitution or replacement of textual material in one language by equivalent textual material in another language" (1995:20). However Kaya notes that the notion of equivalence in this context is problematic. Unlike dictionaries, bilinguals interpret words in context and adjust their translations to ensure their intelligibility in different cultural contexts. According to Leonardi (2000) equivalence is a problematic concept and there is no universal approach to the concept. Natural translators, as defined by Harris, adopt a functional approach and there is evidence that they pay much greater attention to situation and culture than to linguistic correctness in the target language (Harris, 1976).

Malakoff and Hakuta consider that "translation proficiency ... the product of an interplay between metalinguistic maturity and bilingual proficiency" (1991:149). They describe natural translation as consisting of four processes: comprehension of the vocabulary from the source text, comprehension of the meaning, reformulation of the message into the target language, judging the adequacy of the new text. The cognitive skills involved in this process make translation the "metalinguistic skill par excellence" (p146). The authors conclude that "translation provides an easy avenue to enhance linguistic awareness and pride in bilingualism, particularly for minority bilingual children whose home language is not valued by the majority culture" ( $\mathrm{p} 163$ ). Enhanced metalinguistic awareness is also reported as a benefit of bilingualism in Bialystok's work (1991).

Whether to remain close to the source text or reinterpret the text to fit more closely to the target language and culture is one of the key decisions any translator has to make. In Toury's model (1980) 'adequacy' describes a translation close to the source and 'acceptability' one that is closer to the norms of the target language. Most translation is located on a continuum between those two positions. The translator of a text in dual language format needs to work at the 'adequacy' end of the spectrum to ensure that both texts are closely related. This may require making modifications to the source text. Magda and Albana's awareness of the demands of dual language text derives from the experience they have had from the age of 6 of transferring skills from one language to another as they learned to read with such texts in their very multilingual primary school

\section{LEARNING ALBANIAN IN SCHOOL: THE CASE STUDY}

Magda and Albana live in east London and attend a large primary school in which over $80 \%$ of children are bilingual and over 30 different languages are spoken. The school has 
strategies to value and encourage the development of children's home languages which follow Cummins' model. Unable to offer any actual teaching in community languages, it has created language clubs, built relationships with complementary schools and resourced classrooms in materials in community languages including dual language books.

In a Year 1 class, the children, aged 6, are taught by a teacher who is herself bilingual (in Punjabi and English). She chooses dual language books that are available in all the languages of the children in the class, teaching reading to all children using the English texts. The children take the books home and parents are encouraged to read the text in the home language and, if they are interested, to teach them to read. The teacher offers parents advice and support. The use of the same texts in multiple languages enables her to discuss in class the children's experiences of reading at home and their interpretations of the text, even though she is not herself able to read all the languages.

Magda and Albana are close friends. They were both born in London of families who had arrived as refugees from Albania. In an earlier research study (Sneddon, 2008) the girls, then aged 6, were observed as they learned to read in Albanian with their mothers. Both girls spoke only Albanian when they started in the nursery, but rapidly became dominant in English, causing their parents anxiety as their use of Albanian declined. The study revealed the strategies used by the mothers and their daughters. The women taught the Albanian letter-sound correspondence and the girls decoded text carefully, using phonic skills learnt in the English classroom. They then re-read the text more fluently for understanding, asking and answering questions and negotiating meanings with their mothers (whose knowledge of English was still developing). They used the English text to verify meanings. Their knowledge of the whole context of the story, as well as the illustrations, helped them to understand when a word was unfamiliar in both languages. They retold the stories in their own words in both languages.

When the girls started reading with their mothers they were considered moderately competent in reading in English for their age. As suggested by the work of Cummins (1984) and Bialystok (2001), the study revealed a transfer of skills at all levels from English to Albanian: from decoding text to the use of whole-language strategies. By the end of the school year, the mothers reported that both girls had made considerable progress in reading Albanian and were using the language much more in the home and with each other. The intense bilingual work with text appeared to transfer back to their reading skills in English as both were among the very best readers in the class by the end of the year.

As the girls grew in confidence with reading it was suggested to them that they might like to learn to write Albanian. Both agreed to seek help from their mothers to keep bilingual diaries when they both, separately, visited family in Albania during the summer. In due course they turned their diaries into personal narratives in dual text format and illustrated them. These were published by the school, with copies being made available in the school library. The books were popular with their friends and the girls were very proud to have become authors. The school also encouraged children from other language groups to develop dual language books (Sneddon, 2011a). By the time they were in Year 5, aged 10, Magda and Albana were keen to follow the success of their holiday books by writing together a work of fiction. Their teacher provided time for them to work collaboratively. This provided me, as the researcher, with an opportunity to follow their progress in their journey to biliteracy. By the time I started observing and recording them composing in English and translating into Albanian, the school 
had introduced the girls to Shpresa, an Albanian complementary school, which they started attending on Sundays. The activities included Albanian classes, traditional dancing, drama and poetry classes and a range of sporting activities. Both girls, but Magda especially, took part in public performances and both got involved in current affairs that affect refugee communities in London, for example being active in a campaign to end child detention.

Magda and Albana have remained close friends since they started school over 4 years ago. They learned to read Albanian with the same dual language books, they wrote personal books on the same theme and joined the Albanian complementary school within a few weeks of each other. They are equally competent in English and have similar skills in Albanian. Both the composition of the story in the original English and its translation into Albanian have been collaborative exercises.

\section{METHOD OF ENQUIRY}

While my original study of children becoming biliterate using dual language books (which included Magda and Albana, then aged 6) had been designed to explore issues such as the transferability of literacy skills across five different pairs of languages (Sneddon, 2009), the work reported in this paper originated from an opportunity: an invitation from their teacher to follow Magda's and Albana's progress in biliteracy. The suggestion was discussed with the girls themselves and their mothers and written permission obtained from all concerned for several writing sessions to be observed and recorded. Further permission was obtained for the book to be published on the internet. Both girls chose to retain the pseudonyms which they had chosen for the original study.

The girls wrote their text in weekly sessions over a period of two months and three of the sessions were observed, recorded and transcribed. These included composition in English and translation of completed sections into Albanian. In addition to the recordings, interviews were held with teachers and the girls' mothers and the girls were observed at their Albanian class. Based on observations and a transcript of the three sessions, the following analysis focuses on how the girls, untutored in translation and working completely independently, shared their linguistic resources to approach the task of translating from English, their strongest language, into Albanian.

The transcript was discussed line by line with an experienced teacher of both Albanian and English and categories for analysis chosen. The choice of "creating an equivalent meaning" arose from the work of Catford (1995), Kaya (2007) and Harris (1976). This aspect permeated the whole transcript as the girls are intent on communicating their message effectively and creating as accurate a text in Albanian as their knowledge of the language allows. Representative samples were agreed for inclusion in the present paper. Metalinguistic awareness arose from the work of Bialystok (1991) and Malakoff and Hakuta (1991) as one of the common benefits of bilingualism. It was also a theme that emerged from the study of 5 bilingual children learning to read (Sneddon, 2009). As girls aged 6, when learning to read, it was very noticeable that the girls never confused the Albanian and English spelling systems. Both the researcher and the teacher were interested to note how keen the girls were to make their understanding of the differences explicit to the researcher.

The following section describes the strategies Magda and Albana use and what these reveal about their knowledge of how their languages work and how they relate to each other. 
Some months after the publication of their story the girls were invited to comment together on the transcript of the discussion they had during the process of translation, and the negotiation of meaning it revealed. They were also invited, separately, to talk about their recollections and feelings about their journey into biliteracy (Sneddon, 2011b) from the beginning when they started reading with their mothers at age 6 . References to data from both these interviews are included in the data analysis.

\section{THE COMPUTER GEEK - A STORY TRANSLATED}

The Computer Geek / Geek Computri, entirely composed and written by Magda and Albana, tells the story of Jordan, a boy obsessed with gaming on his computer, and how he becomes sucked into a dangerous adventure in a virtual world before his eventual rescue by his grandmother. The girls explained that the inspiration for the story came from films, television programmes and computer games.

As children born in England and initially fairly isolated from the Albanian community, the girls have learned the variety of Albanian that their parents speak in a domestic context. Learning to read in Albanian introduced them to a wider linguistic range. Having composed the story in English, their stronger language, they face the challenge of translating it into their weaker one, as Magda explains

for the English one, we have so many ideas, but this is harder!

In spite of this additional difficulty there is little evidence from the girls' drafts of different registers being used in the two languages. Having used dual language books extensively to learn to read with their mothers, the girls are familiar with their specific conventions and they have worked closely from the English text to produce the Albanian one. Working together from their own linguistic resources, without the use of dictionaries, the girls have access to most of the basic vocabulary they need for their story in Albanian. However there are occasions when they struggle together to find the right shade of meaning, the word that is (as Magda put it) on the top of my nose, and there are a few instances where a simpler expression has been used in Albanian, as when Jordan angrily shouted is translated as Jordani I pergjigjet (Jordan replied).

Both girls enjoy the challenge they face. Magda explains how, in the present state of their knowledge, they prefer to work out solutions for themselves, and how she feels about working with Albana

I think it's much better like this. When you do it with your mums, they always,

like, don't let you speak and if one gets something wrong... you're trying to read this and they just go, no it's whatever. They just say it, they don't let you wait.

\section{a. Creating an equivalent meaning}

The process of translation is negotiated between two children whose language skills are closely matched. The main approach to the task is to take a clause at a time from the English text and discuss it, phrase by phrase, word by word. Some words lead to lengthy exchanges as they attempt to find a shade of meaning or the correct grammatical form, before a whole sentence can fall in to place. As a sentence is completed, one of them repeats it as the other scribes. A typical example of negotiation occurs at the very beginning of the recording. 
Starting where the English text says While he was talking to his Grandma Magda starts with a word-for-word approach, taking 'while' and translating it as nderkohë.

Albana agrees with her choice of word:

Oh yeah, we did that in Albanian class.

Magda then realises that this approach is not appropriate:

We need to do the rest because it won't make sense.

Then she has second thoughts about the word nderkohë and they discuss options.

Magda: Nderkohë ... It doesn't make sense.

Albana: What about, like this: kur ishe, cfarë? (he was, what to put?).

Magda: I don't know it's not, it's nderkohë. While... while... I keep thinking mbasi (maybe) but it's not.

Magda: That's after.

Albana: kur ishte... uhm.

Later a whole clause falls into place as Magda suggests:

Nderkohë qe Jordani ishte tu fol me Gjyshen e tij (while Jordan was talking with his Grandma).

The girls are happy with this phrase and Albana spells out the words as Magda scribes.

Later, another sentence is painstakingly constructed

Magda tries to describe how Jordan reacted when his grandmother suggested he spend less time on his computer.

Magda: Me, what did I say? Me shpejtsi Jordani.... iku tek ... dhoma (quickly Jordan went to his room) Iku tek ... dhoma ...

Albana continues:

E tij (his).

Magda agrees:

E tij. Dhe.

She struggles with the rest of the sentence:

How do you say it? Jordan... On the top of my nose. Te, te... fillon...

Then she feels confident:

Yeah!

She continues:

Luaj...

Albana is hesitant:

I was about to say ...

She trails off and they both laugh at the effort of finding the word that is on the top of my nose.

The girls alternate easily, finishing each other's sentences, giving each other thinking time. Although they occasionally talk at the same time (making the transcription difficult), neither of them dominates and they occasionally suggest the same phrase simultaneously:

Ndoshta shpirt $i$ ime, Ndoshta shpirt $i$ ime, shpirt $i$ ime, shpirt $i$ ime (maybe my sweet pea)

looking at each other as they rehearse the words.

In the later discussion of the transcript, in response to a question about how exactly they were working out the use of the word nderkohë, the girls attempt to explain how, having 
started with trying to translate an individual word, they dealt with the different word order in English and in Albanian.

Albana explains that an expression that makes sense in English may not work in Albanian:

in English, it like, makes sense. And then we try to translate it in Albanian, but it won't work. You have to try and find a word that's exactly like that but makes sense. Yes you need to... In a sentence in English you say it, but in Albanian you swap all the words around.

She goes on to explain that the great debate over the use of nderkohë revolved round a shade of meaning:

It's like meanwhile. But we were trying to find while. And we couldn't think of anything, so we just kept thinking.

Magda explains that using that word required them to change the structure of the Albanian sentence:

We used the word nderkohë but we changed the sentence a little bit in Albanian. So it could make sense.

In a further reflection on the process of translation Magda notes that, in contrast to the long negotiation involved in translating one word:

just sometimes we just read like, I don't know, a whole, if it's like a small paragraph, we read it all and it just comes in your head, you just know it... And then you just have to change it around. You know all the main things, it just comes in your head, but then you add, like, more words and things.

But mostly she finds longer passages more difficult:

But then, like long ones, you just, you do it sentence by sentence, but... I don't know for long ones, it's harder.

Albana nods in agreement.

There is only one instance in which the girls found themselves unable to convey the English meaning in Albanian. The girls try to translate 'when he saw a light on the side of his computer'.

Albana asks:

Ei si thuhet side? (how can we say side?) Side, I don't know. I'm trying to think.

There is a long pause.

Magda sighs and waves her hands around:

I think it might be euh, uhm, I keep wanting to do like that (waving to the side) eueueue.

She groans:

just think of words....

Albana tries to help:

I think it begins with $N$. 
Magda disagrees and they argue, talking over each other. They decide they have to be more specific:

On the right or the left!

Albana suggests:

Not on the right, on the left because it sounds silly if you say on the right.

Magda agrees:

Djatht. Ne majt. Majt, majt (right, left).

She explains to me:

We're changing it to, like, left. Because we don't know.

They settle for Kur ai pa nje dritë ne majt të kompjutrit (he saw a light on the left side of his computer). In their handwritten draft they wrote that the flash came from the left side of the computer and adjusted the English text accordingly.

In a later reflection on this part of the transcript Albana recalls:

We didn't know how to say the side and Magda adds We just suddenly remembered it after we gave in the book and she explains you get frustrated because you just, you're like, it's on the top, it's on the tip of my nose! And you're like, I know it! I know it!

Albana: and you just can't remember it.

Magda: when you want the word, it just won't come in your head! It's like your brain shuts down.... And then, when you're doing something, it just comes!

Albana explains that their teacher offered a further opportunity for corrections:

She didn't publish it straight away and she gave us one more chance to correct everything.

Magda recalls:

And then we were like oh Yeah!

as the right expression, $\mathrm{Në} \mathrm{anë} \mathrm{(on} \mathrm{the} \mathrm{side)} \mathrm{came} \mathrm{to} \mathrm{mind.}$

Magda and Albana's work in translation has been all about finding equivalences from within their shared linguistic resources and the equivalences they produce, often after much debate, are the best they can find. There is one instance where they deviate quite deliberately from a close translation. The grandmother in the English story uses 'sweet pea' as a term of affection and Magda suggest shpirti (my soul, my heart), a widely used term of affection between relatives and close friends, which her mother uses to her. Albana adds:

My mum always did that to my brother when he was little.

\section{b. Metalinguistic awareness.}

Magda and Albana have become increasingly fluent in Albanian as they have read more and had more opportunities to use the language in their complementary school. In the Albanian classes they have recently joined, they have encountered some basic grammar teaching, as they have in English classes in their mainstream school. But, at age 10, they have had few opportunities to explore the structure of the language. In their negotiations to find the right word in Albanian, issues of grammar feature large, although they are not always aware of this. Like many of the natural translators that Harris (1976) refers to, the meaning of their text in Albanian is always fully intelligible. However there are instances where their use of Albanian is non-standard or incorrect. 
For essentially self-taught writers, the girls' overall competence with respect to grammar is good: they use pronouns correctly, they understand the use of the definite and the indefinite article and are able to explain this to me; they make few errors in gender or case when using nouns, they construct compound sentences accurately. However the girls are unsure about where to use an adverb or an adjective, and there are a few apparent errors in the use of verb tenses.

In the first sentence on page 2 of their story they have used the present tense, which is more familiar to them, rather than the past that their narrative requires: Një ditë mbasi shkoplla mbaroj menjëherë Jordani shkoj tek shtepia dhe i tregoj gjushës e ti se çfarë problemi kishte tek shkolle. (One day after school is finished Jordan goes to his grandma and tells her the problem he has with his school).

All three verbs used are in the present: Mbaroj (finish), shkoj (go) and tregoj (tell) should all be mbaroi, shkoi and tregoi, in the past. However, in view of the fact that, in the next sentence, all verbs are correct (ajo ishte tu - he was talking; ajo $\mathbf{i}$ tha - she said) it is possible that, as both forms are pronounced in much the same way, the verbs have simply been misspelt by the girls, who are relying on their knowledge of the spoken language to work out their spelling. The only other example of tense misuse is pergjigjet, in Jordani i pergjigjet (Jordan replies, also on page 2) which has been written in the present rather than the past.

There is comparatively little discussion between the girls about issues that affect the form of the noun. The only error in gender occurs with the word they have used to translate the grandmother's term of endearment, 'sweet pea', shpirti. This is correctly in the masculine gender in the book, but in their original draft the girls wrote Shpirt I ime, in the feminine.

In an aside to me, after a brief disagreement with Magda, Albana explains one of the major differences she has noted between her two languages: the fact that the definite article is expressed as an ending on the noun.

Magda : në kompjutrin. This is, it's so easy to spell, it's a bit like English, it's just that it's got a K instead of a $C$.

RS:

Right, and you spell it like that?

Magda: Kompjuterin means komp - juter - in.

Albana: No! Kompjuter is just like when you say computer, I think when you say THE computer, instead of saying THE, you just say kompjuterin

There are no errors of case in the transcript, Magda correctly writing, for example, në kompjutrin in the example above (në before the noun indicating the accusative case is required). Interestingly, neither girl comments, in the course of the translation, on this additional dimension of variation of nouns in Albanian (which they use correctly throughout) which does not exist in English.

In a later reflection on the transcript Magda explores the two different forms the word for school takes on page 2 and uses the only word she knows to describe this kind of variation in the ending of a word, 'tense'. 
Magda: it's sort of shkolla and shkollë, it's like different tenses.

Albana develops the idea:

Like shkollë is a bit like present tense and shkolla is a bit like past.

Magda: Like you say shkolle mbaroj. That won't make sense. You can say shkollë, but not mbaroj, not finished.... It won't make sense with this, with the word after it.

Albana: Only if you do, only if you do shkollë as the last word then it can make sense.

The girls' last two comments suggest they are aware that the spelling of the word is determined by its role and place in the sentence in a way that does not apply in English.

One of the most debated words in the transcript was the translation of 'serious', when Jordan exclaims 'Grandma this is serious!'

Albana asks:

You know serjoze? I think it's serjozisht, something like that. My Mum says

serjozisht. No, it was serjoze, my mum always says to me like that.

Magda is unsure:

Yes but something, but it's not like kjo eshte (this is) serious. I keep thinking... it's the first one, not the second.

She eventually settles for Kjo eshte serjoze (this is serious).

Albana repeats and agrees:

kjo eshte serjoze, serjoze.

Magda: I keep thinking vertet (really)? Serjoze. (Spelling out as she writes) S E R J O Z E.

The girls have been unsure whether their sentence requires the adjective serjoze or the adverb serjozisht. In the printed text this has been corrected to e kam serjozisht. Both words have been mispelt, probably for the same reason as the verbs mentioned above: the correct spellings being serioze and seriozisht.

The issue comes up again in direct response to a question from me.

RS: So, why were you arguing about that word? What are the two different ways of saying it?

Albana responds with a clarification:

We weren't arguing, we were discussing which one was right.

She tries to explain:

We were like, it's like saying you're serious but, but... that's like saying ...

Magda continues:

about someone, serjozisht is, like I mean, it, it's about saying about yourself. Like, it's what I say. So yours is like he's serious, or she's serious.

The girls are working towards using the right word in context, but they are still not clear about the correct use and, as with the discussion of case above, they lack the terminology to explain the different uses of the word.

\section{c. Spelling}

The girls are very confident when it comes to explaining the differences between the Albanian and English spelling systems and how the greater transparency of Albanian makes it easier to spell words that they know how to pronounce. 
Magda talks about learning to spell Albanian:

When I was smaller my mum always used to say ... I used to ask my mum, how do you spell this, because I was little, and my mum used to be like, just sound it out, I'm not going to help you.

She contrasts this with English:

I used to think to myself, but in English, when I sound it out, like 'have', it's got an $E$, how can I ... how will it work? But then I found out that it's exactly the same. Like, if you say like... 'hour', it's got an $\mathrm{H}$ on it, but there it will just say OUR.

The girls proceed to explain the many digraphs in Albanian and how to pronounce them correctly.

Magda gives the example of the letters GJ in the word gjyshe (grandma):

It's of and it's $g$ you just do $g$ and if it's of, you do $j$.

Albana clarifies and explores the sound:

if you actually pronounce it you can feel it, it's not just $b$, it's like $\boldsymbol{d} d \boldsymbol{b}, \boldsymbol{d} d \boldsymbol{b}$.

Although the Albanian orthography is much more transparent than the English, it is not quite as simple as the girls suggest and their text includes a number of misspellings, such as the ones discussed above where the letter $\mathrm{J}$ sounds similar to I in certain contexts.

\section{DISCUSSION AND CONCLUSION}

I think it's much better like this.

Magda is explicit about the pleasure she gets from working out how to write in Albanian with her friend. It is clear from the transcripts and their body language while they are working wailing when a word eludes them, punching the air when they remember it - that these two untutored translators really enjoy the challenge they have set themselves.

This focused study of Magda and Albana writing bilingually raises issues about children autotranslating (translating their own words) and the pedagogy that supports their work across languages. The bidirectional cognitive competence referred to by Harris and Sherwood (1978) is much in evidence as they make use of all the knowledge they have acquired from school literacy in English, of Albanian as it is used by their parents in the home, of their experience of translated texts in dual language format. If the girls were translating the story orally it is possible that, like the natural translators discussed by Harris (1976), they would be content to convey the message of the story, choosing a word more culturally appropriate to Albanian where necessary (for example translating 'sweet pea' as shpirti).

However, their models are the dual language texts with which they learned to read. Of the four processes described by Malakoff and Hakuta (1991) only the fourth presents a serious challenge. They have no problem with the vocabulary or meaning of the text in English as they wrote it themselves and they can reformulate the text and convey the gist of the meaning in Albanian without too much difficulty. The greatest part of their effort is focused on the adequacy of the new text. Using windows of meaning of varying sizes, they operate a range of strategies, from translating single words to whole phrases or short sentences, to 
solve problems of syntax and morphology as they seek the closest possible equivalences in Albanian to their English text, within the limits of their knowledge of the language. Magda and Albana understand very clearly that their texts will be printed in parallel and have to match each other very closely. It is noticeable that they have avoided metaphors and similes. The one they used (sweet pea) was the subject of substantial debate and explanation. When they find themselves in difficulty in their first draft trying to translate 'at the side of the computer' into Albanian, they decide to change their English text to 'at the left of their computer'.

While their discussions around these problems reveal the girls' implicit metalinguistic understanding, they occasionally verbalise this for the benefit of the researcher. Albana is able to explain how the definite article is expressed in Albanian. However, being untutored in Albanian grammar, the girls lack the technical vocabulary to explain, for example, how cases work (Magda uses the word "tense" to describe the variations in the form of a noun) and have difficulty deciding where an adverb or an adjective is required (serioze/seriozisht).

There is evidence from the work of Magda and Albana, that both learning to read with dual language books (Sneddon, 2009) and learning to write in dual language format has built on their existing communicative skills and extended their vocabulary and use of 'book language', particularly in Albanian. In the process of composing and translating their story the girls reveal how much they know about the conventions of storytelling (Cummins, 2006) and their awareness of their audience. They know how books are made: they planned their illustrations, and the back cover includes an enthusiastic blurb, photographs of themselves taken by their teacher and a notional price of $£ 5$.

There is evidence from the study that the teachers know how to empower bilingual children through valuing and supporting community languages and working closely in partnership with parents and community organisations (Cummins, 1984). In an interview in which the girls were asked to reflect on the process of becoming biliterate, Magda acknowledges the crucial role played by her teachers, who introduced her to dual language books, encouraged her mother to teach her to read, celebrated her achievements and published her books.

The pedagogical strategy of using dual language books for teaching literacy offers many opportunities to both bilingual and monolingual children to explore linguistic diversity in the classroom (Hélot, 2011). It facilitates the transfer of skills across languages (Cummins, 1984; Bialystok, 1991) so that bilingual children who are literate in the language of the home, for example new arrivals educated abroad, are able to understand the meaning of texts being used to teach reading in English; this can accelerate the process of learning to read in English. For children like Magda and Albana who have become dominant in the language of the school, the strategy offers the opportunity to operate a transfer of skills in the opposite direction. This has the particular benefit of enabling the children to extend the range of a language which they may only have learned to use in communicative situations in the domestic domain and to develop academic language.

While learning one language through translation from another is not a good strategy for a new learner, translation can offer many opportunities for working across languages for children who are familiar, in varying degrees, with both. In particular it can support children to improve their access to and develop their weaker language. Biliterate children are known to greatly enjoy critiquing and improving on the translation of a dual language text. The 
books can also be used to introduce monolingual English speakers to world languages and offer opportunities to explore differences and similarities. Activities that encourage children to share their languages can be extended, as they are in this school, into lunchtime language clubs. While there are many ways of valuing the range of languages spoken by children in a multilingual school, the pedagogical practices of this school, by using the languages in the classroom and supporting children's biliteracy, legitimise community languages as languages for learning, and demonstrate how knowledge can be created through working with several languages simultaneously (García, 2009; Hélot, 2011).

The partnership developed with parents resulted in a close engagement of the girls' mothers with the school. This made an impact on the educational opportunities offered to them as they were both supported to acquire qualifications that led to employment as classroom or nursery assistants. The partnership with the complementary school Shpresa raised the profile of Albanian culture in the school and, through offering the girls opportunities to develop their skills in Albanian and their knowledge of Albanian culture, greatly enhanced their confidence and their pride in their personal identities.

The pedagogical strategies of the school have the potential to make a lasting impact on the girls as they themselves acknowledge in an interview after the publication of their second book:

Albana :

I feel happy now because everyone in my school knows that I am Albanian and all my teachers, especially Ms P. and also Ms J., they used to help, they used to always be proud and used to tell all the other teachers how good we were in Albanian and English. I always feel proud to think that I have been good in my language and l've made a book... I think my future will carry on good.

And Magda:

... it might help me in my life if I become an author. Well, I think I am confident now about my future seeing as I'm really confident and been in loads of shows and made two books and I think when I grow up I can do even more things.

(Sneddon, 2011b)

\section{Acknowledgements:}

$X X X X X$

The Computer Geek can be viewed as an e-book at $X X X X$ 


\section{References:}

Bialystok, E. 1991. Metalinguistic Dimensions of Bilingual Language Proficiency. In E. Bialystok, Language Processing in Bilingual Children. Cambridge: Cambridge University Press

Bialystok, E. 2001. The extension of languages through other means. In R. Cooper, L. Shohamy and J. Walters (eds) New Perspectives and Issues in Educational Language Policy. Amsterdam: John Benjamins.

CILT, 2007. Positively Plurilingual. London: CILT, The National Centre for Languages.

CILT, (2008) Our Languages. http://www.cilt.org.uk/commlangs/our langs/ (accessed July 2011)

Blackledge, A. and Creese, A. 2010. Multilingualism. London: Continuum.

Catford, J.C. 1965. A Linguistic Theory of Translation. Oxford: Oxford University Press.

Conteh, J., Martin, P. and Robertson, L.H. 2007. Multilingual learning stories from schools and communities in Britain: Issues and debates. In J. Conteh, P. Martin, and L.H. Robertson, (eds) Multilingual learning stories from schools and communities in Britain. Stoke-on-Trent: Trentham Books.

Cummins, J. 1984. Biingualism and Special Education: Issues in Assessment and Pedagogy. Clevedon: Multilingual Matters.

Cummins, J. 2001. Bilingual Children's Mother Tongue: why is it important for education? Sprogforum (19) 15-20.

Cummins, J. 1986. Empowering Minority Students: a framework for intervention. Harvard Educational Review 56 (1), 18-36

Cummins, J. 1999. Biliteracy, empowerment, and transformative pedagogy. In J. V. Tinajero and R. A. DeVillar (eds.), The power of two languages: 2000. (pp. 9-19). New York:

McGraw-Hill.

Cummins, J. 2000. Language, Power and Pedagogy: Bilingual Children in the Crossfire. Clevedon: Multilingual Matters.

Cummins, J., Bismilla, V., Chow, P., Cohen, S., Giampapa, F., Leoni, L., Sandhu, P., and Sastri, P. 2006. ELL Students Speak for Themselves: Identity Texts and Literacy engagement in Multilingual Classrooms

http://www.curriculum.org/secretariat/files/ELLidentityTexts.pdf (accessed July 2011)

Cummins, J., Early, M. and Stille, S. 2011. Frames of Reference: Identity Texts in Perspective. In J. Cummins and M. Early (eds). Identity Texts: The collaborative creation of power in multilingual schools. Stoke-on-Trent: Trentham Books. 
DfES, 2002. Languages for All: Languages for Life. London: DfES.

DfES, 2003 Aiming High: Raising the Achievement of Minority Ethnic Pupils. London: DfES

DfES, 2006. Learning and Teaching for Bilingual Children in the Primary Years. London: DfES.

Eversley, J., Mehmedbegovic, D., Sanderson, A., Tinsley, T., vonAhn, M., and Wiggins, R.D. 2010. Language Capital: Mapping the languages of London's schoolchildren. London: CILT

García, O. 2009. Bilingual Education in the $21^{\text {st }}$ Century: A Global Perspective. Chichester: Wiley-Blackwell.

Hall, N. 2004. The Child in the Middle: Agency and Diplomacy in Language Brokering Events'. In G. Hansen, K. Malmkjaer and D. Gile, (eds), Claims, Changes and Challenges in Translation Studies (Benjamins Translation Library 20) Amsterdam: John Benjamins.

Hall, N. and Robinson, A. 1999. The Language Brokering Behaviour of Young Children in Families of Pakistani Heritage. http:

//www.esri.mmu.ac.uk/resprojects/brokering/Pakistani.doc.1999. (Accessed July 2011).

Harris, B. 1976. The importance of natural translation. Working Papers in Bilingualism (Toronto) 12.96-114, 1-17

Harris, B and Sherwood, B. 1978. Translating as an innate skill. In D. Gerver, and W.H. Sinaiko, (eds) Language Interpretation and Communication (Proceedings of the NATO Symposium on Language Interpretation and Communication, Giorgio Cini Foundation, Venice, 1977) Oxford: Plenum 155-170

Hélot, C. 2011. Children's Literature in the Multilingual Classroom: Developing Multilingual Literacy Acquisition. In C. Hélot, and M. O Laoire, Language Policy for the Multilingual Classroom. Pedagogy of the possible. Bristol: Multilingual Matters.

Kaya, B. 2007. The role of bilingualism in translation activity. Translation Theory, 11:1. No pagination. http://accurapid.com/journal/39bilingual.htm. Accessed July 2011.

Kenner, C, Gregory, E, Ruby, M, and Al-Azami, S. 2008a Bilingual learning for second and third generation children. Language, Culture and Curriculum 21,2 p120-137.

Kenner, C, Al-Azami, S, Gregory, E. and Ruby, M. 2008b. Bilingual poetry: expanding the cognitive and cultural dimensions of children's learning. Literacy 42,2 p92-100.

Leonardi, V. 2000. Equivalence in Translation: between myth and reality. Translation Theory 4 (4) No pagination. http://translationjournal.net/journal/14equiv.htm. (Accessed July 2011).

Malakoff, M and Hakuta, K 1991 Translation Skill and Metalinguistic Awareness in Bilinguals. In E. Bialystok, Language Processing in Bilingual Children. Cambridge: Cambridge University Press

Martin, P. Bhatt, A. Bhojani N. and Creese, A. 2006. Managing bilingual interaction in a 
Gujarati complementary school in Leicester. Language and Education 20, 1: 5-23.

Ruíz, R. 1984. Orientations in language planning. National Association for Bilingual Education (NABE) Journal 8 (2), 15-34.

Sneddon, R. (2008) Magda and Albana: Learning to read with dual language books. Language and Education 22 (2), 137-154.í

Sneddon, R. (2009) Bilingual Books - Biliterate Children. Stoke-on-Trent: Trentham Books.

Sneddon, R. (2011a) The Dragon in the Jungle / Le Dragon dans la Jungle. Race Equality Teaching 30 (1) 16-20.

Sneddon, R. (2011b) Two languages, Two Voices: Magda and Albana become authors. In G. Czerniawsky and W. Kidd, (eds) The Student Voice Handbook: Bridging Academic / Practitioner Divide. Bingley: Emerald

Toury, G. 1980. In search of a theory of translation. Tel-Aviv: Porter Institute for Poetics and Semiotics

Valdés, G. 2003. Expanding Definitions of Giftedness: The Case of Young Interpreters from Immigrant Communities. Educational Psychology Series. Mahwah NJ: Laurence Erlbaum.

Vertovec, S. 2007. New Complexities of Cohesion in Britain: super-diversity, transnationalism and civil-integration. Commission on Integration and Cohesion. Wetherby: Communities and Local Government Publications. 